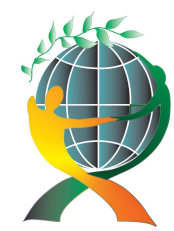

\author{
(online) $=$ ISSN $2285-3642$ \\ ISSN-L = $2285-3642$ \\ Journal of Economic Development, Environment and People \\ Volume 7, Issue 4, 2018
}

URL: http://iedep.spiruharet.ro

e-mail: office jedep@spiruharet.ro

\title{
Crunch of Sharia Banking Credit during Global Crisis
}

\author{
Eko Wiratno ${ }^{1}$, Lukman Hakim ${ }^{2}$ and Akhmad Daerobi ${ }^{2}$ \\ ${ }^{1}$ Mahasiswa Pascasarjana Universitas Sebelas Maret, Surakarta, Indoneisa \\ ${ }^{2}$ Dosen Pascasarjana Universitas Sebelas Maret, Surakarta, Indonesia
}

\begin{abstract}
This research was conducted examining factors which influences financial crunch as seen from the perspective of financing supply and demand sharia bank in Indonesia from January 2003 - June 2015. The secondary data were obtained from Statistics Indonesia (BPS), Bank Indonesia (BI) and Financial Services Authority (OJK). This research conducted with Two Stage Least Square (TSLS) approached.

The results showed that financial crunch did not occured in sharia banking in Indonesia from January 2003-June 2015, Third Party Fund (DPK) negatively and significantly influences sharia banking financing supply, Non-Performing Financing (NPF) positively and non-significantly influences sharia banking financing supply, Profit Sharing Rate (TBH) positively and significantly influences sharia banking financing supply, Bank Indonesia Wadi'ah Certificate (SWBI) positively and non-significantly influences sharia banking financing supply, Bank Indonesia Certificate (SBI) positively and significantly influences sharia banking financing demand and Gross Domestic Product (PDB) positively and significantly influences sharia banking financing demand.
\end{abstract}

Keywords: financing, sharia bank, financial crunch, two stage least square (TSLS)

\section{JEL Codes: 0160}

\section{Introduction}

Financial crunch is an economic phenomenon in which bank financing cannot be maximally distributed to real sectors. A situation where bank financing supply decreases is caused by bank's decreased interest in financing distribution. The reason of this phenomenon may be viewed from financing supply and demand perspectives. From supply perspective, financial crunch takes place as a result of excessive caution taken by banks in selecting customers as result of a trauma such as economic crisis. While from demand perspective, financial crunch is caused by customers' low interest in borrowing money, as the result of too high risk to be assumed (Hakim and Rahayu, 2007). Some researchers, such as Agung (2001), propose that financial crunch in Indonesia during economic crisis between 1997-2001 is caused by supply instead of demand.

\footnotetext{
$+\quad$ Corresponding author. Tel.: + (6281390877580)

E-mail address: (ekowiratno1984@gmail.com).
} 


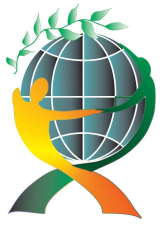

\author{
(online) $=$ ISSN $2285-3642$ \\ ISSN-L = $2285-3642$ \\ Journal of Economic Development, Environment and People \\ Volume 7, Issue 4, 2018 \\ URL: http://iedep.spiruharet.ro \\ e-mail: office jedep@spiruharet.ro
}

The development of sharia banking in Indonesia has become a benchmark of success of sharia economy existence. The monetary crisis that happened in 1998 has drowned conventional banks and many of it were liquidated because of their interest system failure. Meanwhile, banks which apply sharia system continue to exist and survive, as evidenced Bank Muamalat Indonesia's success to pass the 1998 crisis, which showed increase performance without Government's assistance, and it even gain profit of more than Rp. 300 Billion (Swandayani and Kurniasih, 2012).

Several studies shows that the reasons of bank financing decreasing distribution to private sectors in Asia, after the 1997 crisis, are still debated by economists (Agenor, 2004). Some economists argue that the decrease of bank financing distribution is caused by financial crunch which gives rise to credit rationing phenomena, thus bank financing supply decreases (supply side constraint). Other economists argue that the decrease of bank financing distribution is caused by the decrease of financing demand (demand side constraint), as a logical consequence of aggregate demand contraction and output decrease after crisis.

According to Agenor (2004), distribution justify why shrinking bank financing is a demand factor or financing supply factor, having important implication in fiscal and monetary policies. For example, if banks are reluctant to distribute financing since they consider that, in case of failure,there is a higher risk which cannot be internalized with borrowing cost increase, fiscal policy which tries to increase liquidity in order to stimulate aggregate demand will not effectively increase financing demand. On the contrary, in case of low financing distribution, this is because business sectors reduce their demand for financing, since they consider weak future demand (demand side), expansion fiscal policy may be able to promote aggregate demand and financing expansion. From monetary policy perspective, financial crunch which happens because banks are reluctant to distribute financing causes relatively freed up monetary policy which cannot be transmitted to real sector through lending. In addition, financial crunch may also reduce the movement space for monetary policy, since in such condition, interest rate raising monetary policy will worsen business world condition.

\title{
2. Method
}

The data are obtained from formal and non-formal documents and publications of BPS, Bank Indonesia and OJK. The data which will be used are in the form of consecutively monthly data from January 2003 to June 2015, pursuant to what the research needs, in the form of aggregate data of financing condition and characteristics of all Sharia Banks in Indonesia obtained from Bank Indonesia. The free variables in this research are Financial Crunch, Third Party Fund (DPK), Non Performing Financing (NPF), Profit Sharing Rate (TBH), Bank Indonesia Certificate (SBI), Bank Indonesia Wadi'ah Certificate (SWBI) and Gross Domestic Product (PDB).

\subsection{Data Stationarity Test}

A unit roots test was created to examine whether the time series data in use are stationary or not. This test is required to make the data stationary, since non-stationary data will result in spurious regression phenomenon, which is regression which describes the relationship of two or more variables which appear statistically significant while in fact is not as high as the resulted regression. According to Granger, and Newbold, in Gujarati (2003) a characteristic of false regression is $R^{2}>$ Durbin Watson Statistic value, thus it will cause autocorrelation.

A method to test data stationarity is The Augmented Dickey-Fuller (ADF) test, which is an expansion of DF test and has the following three alternative models Gujarati (2003). 


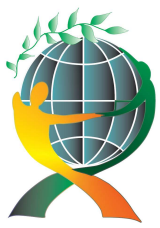

\author{
(online) $=$ ISSN $2285-3642$ \\ ISSN-L = $2285-3642$ \\ Journal of Economic Development, Environment and People \\ Volume 7, Issue 4, 2018 \\ URL: http://iedep.spiruharet.ro \\ e-mail: office jedep@spiruharet.ro
}

Whether stationary data may or may not be examined, is viewed by comparing between DF or ADF statistic value with the critical value. If the DF or ADF absolute statistic value is higher than the critical value, the data are stationary and if otherwise, the data are not stationary.

\title{
2.2 Model Estimation.
}

Financial crunch test is conducted by identifying whether financing distributed by sharia banks is caused more by supply or demand. This identification is conducted using simultaneous equation to obtain information whether actual existing financing can be connected to financing supply or financing demand function. Sharia commercial bank balanced financing demand and supply are achieved when

\section{Ln SPem = Ln DPemb}

If the financing market is perfectly working, profit sharing rate will always be adjusted to ensure that supply is equal to demand. However, when financing is not perfectly working, in which profit sharing rate is not adjusted or financial crunch takes place, then financing supply (SPem) is not always equal to financing demand (DPemb), thus the financing level may be formulated as follows:

$\mathrm{Pem}_{\mathrm{t}}=\min ($ Ln SPem $=$ Ln DPemb)

In this empirical model, real financial supply (LS) is determined by DPK, NPF, TBH and SWBI. The relationship may mathematically be written as follows.

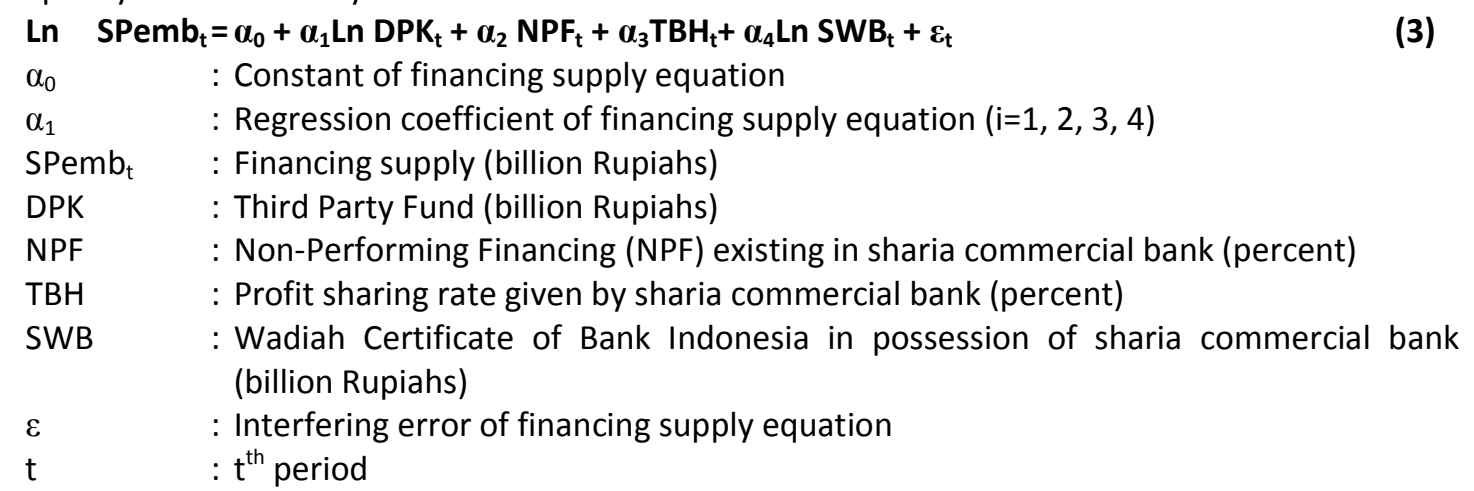

In the financing demand, it is determined by profit sharing rate, PDB and interest rate of Bank Indonesia Certificate. The formal specifications of sharia bank financing demand as follows:

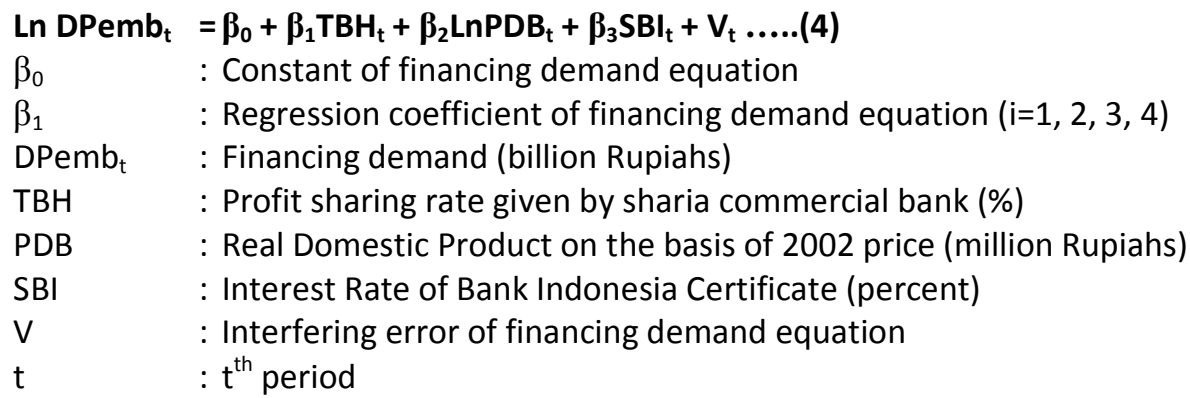

\subsection{Significance Test}

The significance test employ the Two Stage Least Square (TSLS) method, with assistance of E-views software. These model estimation and significance test aim at observing whether the supply 


\author{
(online) $=$ ISSN $2285-3642$ \\ ISSN-L = $2285-3642$ \\ Journal of Economic Development, Environment and People \\ Volume 7, Issue 4, 2018
}

URL: http://iedep.spiruharet.ro

e-mail: office jedep@spiruharet.ro

model estimation is relatively good for use and whether the independent variables significantly influence the dependent variables.

\title{
3. Result and Discussion
}

\subsection{Descriptive Statistics}

The descriptive statistics of all research variables covering average value, mean value, maximum, minimum and standard deviation are given in the Table.

Table 3.1 Table of Descriptive Statistics of Research Variables

\begin{tabular}{|l|c|l|l|c|c|c|c|}
\hline & BAGI HASIL & \multicolumn{1}{c|}{ DPK } & NPF & PDB & PEMB & SBI & SWBI \\
\hline Mean & 11.76340 & 4806939 & 3.935533 & 5647721 & 69948.51 & 7.892867 & 1921.645 \\
\hline Median & 12.46000 & 88916.00 & 3.890000 & 5417237 & 39807.50 & 7.500000 & 1549.200 \\
\hline Maximum & 17.76000 & 20668826 & 7.340000 & 9993816 & 217321.0 & 12.75000 & 4421.410 \\
\hline Minimum & 5.000000 & 19688.33 & 2.320000 & 1910800 & 3357.000 & 5.750000 & 220.6800 \\
\hline $\begin{array}{l}\text { Deviation } \\
\text { Standard }\end{array}$ & 2.133742 & 6242275 & 1.149823 & 2666397 & 67577.50 & 1.892748 & 1247.430 \\
\hline
\end{tabular}

\subsection{Data Stationarity Test Results}

Before model estimation with TSLS, a standard procedure is performed first to test whether the data contain unit root, which means that the data are not stationary or, on the contrary, the data do not contain unit root, which means that the data are stationary. The ADF (Augmented Dickey-Fuller) test is employed to test the stationary of data.

Tabel 3.2 Table of Data Stationarity Test Results

\begin{tabular}{|l|c|c|c|c|}
\hline \multicolumn{1}{|c|}{ Variable } & \multirow{2}{*}{ Symbol } & \multicolumn{2}{c|}{ ADF Test Statistic ${ }^{*}$ ) } & \multirow{2}{*}{$\begin{array}{c}\text { First } \\
\text { Difference }\end{array}$} \\
\cline { 3 - 5 } & & $\begin{array}{c}\text { Level } \\
\text { (P Value) }\end{array}$ & - & \multirow{2}{*}{ Stationation } \\
\hline $\begin{array}{l}\text { Sharia Commercial } \\
\text { Bank Financing }\end{array}$ & Ln SPemb & -4.072702 & Stationary \\
\hline Third Party Fund & Ln DPK & -12.26367 & - & Stationary \\
\hline $\begin{array}{l}\text { Non-Performing } \\
\text { Financing }\end{array}$ & NPF & -2.710516 & Stationary \\
\hline $\begin{array}{l}\text { Profit sharing rate } \\
\text { given by sharia } \\
\text { commercial bank } \\
\text { (percent) }\end{array}$ & TBH & -3.814988 & - & Stationary in first \\
\hline $\begin{array}{l}\text { Bank Indonesia } \\
\text { Wadiah Certificate in } \\
\text { possession of sharia } \\
\text { commercial bank }\end{array}$ & Ln SWBI & -2.130718 & -10.62636 & difference \\
\hline
\end{tabular}




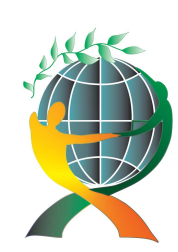

\author{
(online) $=$ ISSN $2285-3642$ \\ ISSN-L = $2285-3642$ \\ Journal of Economic Development, Environment and People \\ Volume 7, Issue 4, 2018
}

URL: http://iedep.spiruharet.ro

e-mail: office jedep@spiruharet.ro

\begin{tabular}{|l|c|c|c|c|}
\hline $\begin{array}{l}\text { Real Domestic } \\
\text { Product on the basis } \\
\text { of } 2002 \text { price (million } \\
\text { Rupiahs) }\end{array}$ & Ln PDB & -3.443189 & - & Stationary \\
\hline $\begin{array}{l}\text { Bank Indonesia } \\
\text { Certificate Interest } \\
\text { Rate }\end{array}$ & SBI & -2.609522 & - & Stationary \\
\hline
\end{tabular}

The Table above shows that the data in use are mostly stationary at data level, while only one variable, which is Bank Indonesia Wadiah Certificate owned by sharia commercial bank, will be stationary in first difference.

\title{
3.3 Regression Analysis on Financing Supply
}

The results of TSLS estimation on sharia financing supply equation in the sample period of January 2003 - July 2015 (150 observations) are briefly presented in Table 3.3

Table 3.3 Estimation of Sharia Banking Financing Supply Function

\begin{tabular}{|c|c|c|c|c|}
\hline \multirow[t]{2}{*}{ Variable } & Coefficient & Statistics & Probability & Coefficient Mark \\
\hline & \multicolumn{4}{|c|}{ Financing Supply } \\
\hline Constant & 10.42274 & 24.43504 & 0.0000 & \\
\hline $\begin{array}{l}\text { PROFIT_SHARING/ } \\
\text { TBH }\end{array}$ & 0.030549 & 1.134269 & 0.2576 & + \\
\hline DPK & -0.141480 & $-6.757953^{*}$ & 0.0000 & - \\
\hline NPF & 0.120885 & 2.566946 & $0.0108^{*}$ & + \\
\hline SWBI & -0.000615 & 11.85828 & $0.0000 *$ & + \\
\hline \multicolumn{3}{|c|}{$\begin{array}{ll}\text { R-squared } & 0.796993 \\
\text { F-statistic } & 142.3152\end{array}$} & \multicolumn{2}{|c|}{ Durbin-Watson stat 0.246916} \\
\hline
\end{tabular}

Note: * Significant at $\alpha=0.05$;

Based on the estimation results in Table 3.3, the R-Square value is 79.6993 percent, which is used to test the goodness-of-fit of regression model and means that 79.7 percent of sharia banking financing supply can be explained with independent variables, while the remaining 20.3 percent is explained with other reasons.

Simultaneous tests with F-statistical test. This test aims at examining whether all independent variables simultaneously, significantly influence dependent variables as viewed from the probability value of F-count using significance level of $\alpha=0.05$. The F-count results show that the equation has $F$ count probability higher than the $\alpha$ value, thus we may conclude that all independent variables do insignificantly, simultaneously influence dependent variables with trust degree close to 95 percent.

Furthermore, t-test is used to observe whether or not the relationship between independent variables and dependent variables is individually significant according to its probability at significance level of $\alpha=$ 0.05 . 


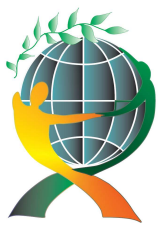

\author{
(online) $=$ ISSN $2285-3642$ \\ ISSN-L = $2285-3642$ \\ Journal of Economic Development, Environment and People \\ Volume 7, Issue 4, 2018
}

URL: http://iedep.spiruharet.ro

e-mail: office jedep@spiruharet.ro

According to the t-test results, we may conclude that each independent variable (NPF, TBH, SWBI) does insignificantly, individually influences sharia banking financing supply in Indonesia, however, DPK independent variable significantly, individually influences sharia banking financing supply in Indonesia.

The analysis results show that sharia bank profit sharing rate positively and significantly influences such banking financing supply. The regression coefficient is 0.030549 , which means that if the profit sharing rate increases by $10 \%$, the sharia banking financing supply increases by $0.3 \%$. The influence of profit sharing rate on sharia banking financing supply is very elastic.

The analysis results also show that DPK (Third Party Fund) negatively and significantly influences sharia banking financing supply. The regression coefficient is -0.141480 , which means that if DPK increases by $1 \%$, the sharia banking financing supply decreases by $0.14 \%$.

NPF (Non-Performing Financing) positively and insignificantly influences sharia banking financing supply. The regression coefficient is 0.120885 , which means that if NPF increases by $10 \%$, the sharia banking financing supply increases by $12.08 \%$. The influence of NPF on sharia banking financing supply is fairly elastic.

SWBI (Bank Indonesia Wadi'ah Certificate) positively and insignificantly influences sharia banking financing supply. The regression coefficient is 0.000615 , which means that if SWBI increases by $10 \%$, the sharia banking financing supply increases by $0.0615 \%$. The influence of SWBI on sharia banking financing supply is very elastic.

\title{
3.4 Regression Analysis on Financing Demand
}

The results of TSLS estimation on sharia financing demand equation in the sample period of January 2003-Juli 2015 (150 observations) are briefly presented in Table 3.4

The estimation results show that the factors equation model which influences sharia banking financing demand has determination coefficient $\left(R^{2}\right)$ of 0.980608 . This determination coefficient value may be interpreted that sharia banking financing demand may be explained by $\mathrm{TBH}, \mathrm{PDB}$, and SBI variables by $98.06 \%$, while the remaining $1.94 \%$ is explained by other variables.

Table 3.4 Estimation of Sharia Banking Financing Demand Function

\begin{tabular}{|l|r|r|r|c|}
\hline Variable & \multicolumn{1}{|l|}{ Coefficient } & \multicolumn{1}{|l|}{ Statistics } & Probability \\
\hline & Financing Supply & $0.0000^{*}$ & \\
\hline Constant & -24.68159 & -42.19231 & $0.0015^{*}$ & - \\
\hline BAGI_HASIL & -0.023995 & -3.200449 & $0.0000^{*}$ & + \\
\hline PDB & 2.294280 & 61.44538 & $0.00225^{*}$ & + \\
\hline SBI & 0.021276 & 2.294523 & \multicolumn{2}{|c|}{ Durbin-Watson stat 0.069616 } \\
\hline $\begin{array}{l}\text { R-squared } \\
\text { F-statistic 2460.952 }\end{array}$ & & \\
\hline
\end{tabular}

Note: * Significant at $\alpha=0.05$

Simultaneous F-statistical tests show that the F-statistical value is higher than the significance level of 0.05 , thus we may say that all independent variables insignificantly, simultaneously influence dependent variables with trust degree of 95 percent. 


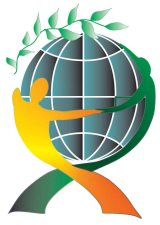

\author{
(online) $=$ ISSN $2285-3642$ \\ ISSN-L = $2285-3642$ \\ Journal of Economic Development, Environment and People \\ Volume 7, Issue 4, 2018 \\ URL: http://iedep.spiruharet.ro \\ e-mail: office jedep@spiruharet.ro
}

Individual test is performed with t-statistic test. We may view in Table 3.4 that the probability of each $\mathrm{t}$-statistic test is significant for all independent variables, which are TBH, PDB and SBI, each of which is significant with significance level of 5 percent.

The analysis results show that sharia banking profit sharing rate negatively and significantly influences the banking financing demand. The regression coefficient is -0.023995 , which means that if profit sharing rate increases by $10 \%$, the sharia banking financing demand decreases by $2.39 \%$. The influence of profit sharing rate on sharia banking financing demand is less elastic.

The analysis results also show that PDB (Gross Domestic Product) positively and significantly influences sharia banking financing demand. The regression coefficient is 2.294280; which means that if PDB increases by $10 \%$, the sharia banking financing demand increases by $22.94 \%$. The influence of PDB on sharia banking financing demand is very elastic.

SBI (Bank Indonesia Certificate) positively and significantly influences sharia banking financing demand. The regression coefficient is 0.021276 , which means that if SBI increases by $10 \%$, sharia banking financing supply demand increases by $2.12 \%$. The influence of SBI on sharia banking financing supply is very elastic.

\title{
3.5 Research Results Interpretation
}

\section{a. Sharia Crunch from Supply Perspective}

The decrease of financing fund may be viewed from decreasing demand or supply for banking financing. The real empirical results of sharia banking financing supply (SPembt) is determined by Profit Sharing Rate (TBH), Third Party Fund (DPK), Non-Performing Financing (NPF) and Bank Indonesia Wadiah Certificate (SWBI) in possession of sharia commercial bank. The real empirical results of sharia banking financing demand (DPembt) is determined by Profit Sharing Rate (TBH), Gross Domestic Product (PDB) and Bank Indonesia Certificate (SBI).

The elasticity value of profit sharing on sharia banking financing supply is very high, implying that sharia banks' depositors are highly influenced by profit sharing offered by sharia banks. Profit sharing margin provides relatively higher profit than interest offered by conventional bank, since the profit sharing system given is based on a profit ratio agreed on when a customer open an account. In addition, during monetary crisis period, sharia banks still show better performance compared to conventional banking institutions (Banowo and Budi, 2005). Ani and Wasilah (2010) in their research conclude that profit sharing significantly influences mudharabah deposit. Profit Sharing Rate significantly influences mudharabah deposit. Haron and Azmi (2000) in their research conclude that there is positive relationship in profit sharing system.

The analysis results also show that DPK (Third Party Fund) negatively influences sharia banking financing supply. However, the research results show that when DPK increases, financing fund distributed by sharia banks continuously decreases.

The research results imply that sharia banks more carefully provide financing when more funds are collected. They prefer investing money in a safer way like in other banks, thus DPK growth is not proportional to financing growth. Besides, that sharia banks' source of fund distributed for financing other than Third Party Fund is also in the form of committed or uncommitted investment, thus the amount of distributed financing does not entirely depend on Third Party Fund.

NPF (Non-Performing Financing) positively and significantly influences sharia banking financing supply. The estimation results show that when NPF increases by $10 \%$, financing will increases by $12.08 \%$. 


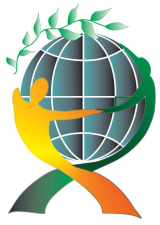

\author{
(online) $=$ ISSN $2285-3642$ \\ ISSN-L = $2285-3642$ \\ Journal of Economic Development, Environment and People \\ Volume 7, Issue 4, 2018 \\ URL: http://iedep.spiruharet.ro \\ e-mail: office jedep@spiruharet.ro
}

SWBI (Bank Indonesia Wadi'ah Certificate) positively and significantly influences sharia banking financing supply. The regression elasticity coefficient is 0.00615 , implying that the influence of SWBI on sharia banking financing supply is inelastic.

\title{
b. Sharia Crunch from Demand Perspective
}

The real empirical result of sharia banking financing demand (DPembt) is determined by Profit Sharing Rate (TBH), Third Party Fund (DPK), Gross Domestic Product (PDB) and Bank Indonesia Certificate (SBI) in possession by sharia commercial bank.

The elasticity value of profit sharing on sharia banking financing demand is $-2.39 \%$, showing that the profit sharing rate increases by $100 \%$ and decreases financing demand by $2.39 \%$. PDB (Gross Domestic Product) positively and significantly influences sharia banking financing demand. The regression coefficient is 2.294280 , implying that the influence of PDB is very elastic. This implies that increasing economy growth will increase financing demand, and, on the contrary, in a weakening economy condition (recession), financing demand tends to decrease.

SBI (Bank Indonesia Certificate) positively and significantly influences sharia banking financing demand. The regression coefficient is 0.021276 , implying that the influence of SBI on sharia banking financing demand is inelastic.

\section{References}

[1] Hakim, L., Rahayu, S.A.T. 2007. Model Kegentingan Pembiayaan Bank Syariah Pada Masa Krisis. Penelitian Dosen Muda 2007. http://lukmanhakim.staff.fe.uns.ac.id .

[2] Agung, J. 2001. Financial Crunch di Indonesia setelah Krisis. Jakarta: Bank Indonesia.

[3] Agenor, P.R. 2004. The Economics of Adjustment and Growth: Second Edition. Harvard University Press.

[4] Ani, A dan Wasilah. 2010. Faktor-faktor yang mempengaruhi jumlah penghimpunan dana pihak ketiga. Simposium Nasional Akuntansi XIII.

[5] Banowo,E dan Budi, H. 2005. Hubungan Equivalent Rate Simpanan Mudharabah dengan Sertifikat Wadiah dan Sertifikat Bank Indonesia.

[6] Eviews 4 Users Guide. 2001. http://eviews.com

[7] Gujarati, D. 2003. Perbandingan Peranan Jalur Pembiayaan Pada Masa dan Sebelum Krisis 1990.1-2000.4 dalam Lukman Hakim et al. Beberapa Agenda Perekonomian Indonesia: Kritik dan Solusi. Jakarta: DRFE Usakti.

[8] Haron, S dan Azmi, W. N. W. 2008. Determinants of Islamic and Conventional Deposits in The Malaysian Banking System. Managerial Finance vol 34(9).

[9] Swandayani, M.D., Kusumaningtyas, R. 2012. Pengaruh Inflasi, Suku Bunga, Nilai Tukar Valas dan Jumlah Uang Beredar terhadap Profitabilitas pada Perbankan Syariah di Indonesia Periode 2005-2009. Akrual 3 (2): 147-166.

[10] http://www.bps.go.id

[11] http://www.ojk.go.id

[12] http://www.bi.go.id 